\title{
Biological and Molecular Properties of Wild potato mosaic virus Isolates from Pepino (Solanum muricatum)
}

\author{
Cesar E. Fribourg, ${ }^{1}$ Adrian J. Gibbs, ${ }^{2}$ Ian P. Adams, ${ }^{3}$ Neil Boonham, ${ }^{4}$ and Roger A. C. Jones, ${ }^{5 \dagger}$ \\ ${ }^{1}$ Departamento de Fitopatologia, Universidad Nacional Agraria, La Molina, Lima, Peru \\ ${ }^{2}$ Emeritus Faculty, Australian National University, Canberra, ACT, Australia \\ ${ }^{3}$ Fera Science Ltd., Sand Hutton, York, U.K. \\ ${ }^{4}$ Institute for Agrifood Research Innovations, Newcastle University, Newcastle upon Tyne, U.K. \\ ${ }^{5}$ Institute of Agriculture, University of Western Australia, 35 Stirling Highway, Crawley, WA, Australia, and Department of \\ Primary Industries and Regional Development, 3 Baron-Hay Court, South Perth, WA, Australia
}

\begin{abstract}
In 1976, a virus with flexuous, filamentous virions typical of the family Potyviridae was isolated from symptomatic pepino (Solanum muricatum) plants growing in two valleys in Peru's coastal desert region. In 2014, a virus with similar-shaped virions was isolated from asymptomatic fruits obtained from pepino plants growing in six coastal valleys and a valley in Peru's Andean highlands. Both were identified subsequently as Wild potato mosaic virus (WPMV) by serology or highthroughput sequencing (HTS). The symptoms caused by two old and seven new isolates from pepino were examined in indicator plants. Infected solanaceous hosts varied considerably in their sensitivities to infection and individual isolates varied greatly in virulence. All seven new isolates caused quick death of infected Nicotiana benthamiana plants and more than half of them killed infected plants of Physalis floridana and $S$. chancayense. These three species were the most sensitive to infection. The most virulent isolate was found to be BA because it killed five of eight solanaceous host species whereas CA was the least severe because it only killed $N$. benthamiana. Using HTS, complete genomic sequences of six isolates were obtained, with one isolate (FE) showing

evidence of recombination. The distances between individual WPMV isolates in phylogenetic trees and the geographical distances between their collection sites were found to be unrelated. The individual WPMV isolates displayed nucleotide sequence identities of 80.9-99.8\%, whereas the most closely related virus, Potato virus V (PVV), was around $75 \%$ identical to WPMV. WPMV, PVV, and Peru tomato virus formed clusters of similar phylogenetic diversity, and were found to be distinct but related viruses within the overall Potato virus $Y$ lineage. WPMV infection seems widespread and of likely economic significance to pepino producers in Peru's coastal valleys. Because it constitutes the fifth virus found infecting pepino and this crop is entirely vegetatively propagated, development of healthy pepino stock programs is advocated.

Keywords: American lineage, disease management, economic significance, etiology, high-throughput sequencing, host sensitivity to infection, isolate virulence, pathogen detection, pathogen diversity, pepino, Peru, phylogenetic analysis, bush fruit, symptomatology, virions, viruses and viroids, widespread infection, Wild potato mosaic virus.
\end{abstract}

Pepino (Solanum muricatum) is a perennial bush fruit crop first domesticated in the Andean region of South America well before the era of the Inca empire. It is currently grown at altitudes ranging from close to sea level up to $3,000 \mathrm{~m}$, grows best under warm conditions, is propagated only from cuttings, and produces a sweet fruit which tastes like melon. It is sometimes called "pepino dulce" (dulce = sweet) to distinguish it from cucumber (Cucumis sativus) which is called "pepino" in Spain and produces fruit that are not sweet. Due to pepino's sensitivity to chilling, pests, and diseases, its crops are replanted annually. Because there has never been a pepino breeding program in South America, its culture in the Andean region depends entirely on traditional land races. These are grown in different locations and their fruit differ in shape, size, and skin coloration. Recently, pepino became adopted as a crop by several other countries, including New Zealand, Australia, Spain, Turkey, Israel, and China, in some of which pepino breeding is underway to improve

${ }^{\dagger}$ Corresponding author: Roger A. C. Jones; roger.jones@uwa.edu.au

Funding: Operating funds in Lima were provided by the International Potato Center in 1976 to 1978 and National Agrarian University in 2014 to 2016: in 2016 to 2017 in York they were provided by the U.K. Government's Department of Environment Food and Rural Affairs (DEFRA) Future Proofing Plant Health Project.

The author(s) declare no conflict of interest.

Accepted for publication 22 February 2019.

(c) 2019 The American Phytopathological Society the crop (Blanca et al. 2007; Herraiz et al. 2015, 2016; Prohens et al. 1996).

In the coastal desert region of Peru, rivers that flow from the Andes mountains down to the Pacific Ocean are used to irrigate crops, including pepino, a crop grown mostly by smallholder farmers. In 1974, two viruses were found infecting symptomatic pepino plants growing in irrigated crops in the same coastal desert region. These were the Andean strain of Potato virus $S$ ( $\mathrm{PVS}^{\mathrm{A}}$; genus Carlavirus, family Betaflexiviridae) and a new virus named Pepino mosaic virus (PepMV; genus Potexvirus, family Alphaflexiviridae) (Jones et al. 1980). In 1976, a third virus was isolated from pepino plants growing in the same region. It had 750-nm flexuous, filamentous particles typical of the genus Potyvirus (family Potyviridae) (R. A. C. Jones, unpublished data). In 1986, this potyvirus was reisolated from pepino fruit and identified by inoculation to indicator hosts and serology as Wild potato mosaic virus (WPMV) (C. E. Fribourg, unpublished data). WPMV had been found earlier (in 1974) in naturally infected plants of the wild potato species $S$. chancayense showing symptoms of severe mosaic and leaf deformation growing in "mist-watered" natural vegetation known as the "Lomas" in the Peruvian coastal desert region (Dillon 2005; Jones and Fribourg 1979, 1990). In addition, in the 1970s, two other viruses were found infecting pepino crops in the same region, Cucumber mosaic virus (CMV; genus Cucumovirus, family Cucumoviridae) (Fernandez-Northcote et al. 1982), and Tomato mosaic virus (ToMV; genus Tobamovirus, family Virgaviridae (C. E. Fribourg, unpublished data). Also, another virus, initially called Pepino latent virus, was detected infecting pepino cuttings introduced to New Zealand from Chile but was subsequently shown to be PVS ${ }^{\text {A }}$ (Dolby and Jones 1988; Santillan et al. 2018; Thomas et al. 1980). Occurrence of all of these viruses in a crop that is only propagated vegetatively, depends entirely on local 
land races, and for which no healthy stock program is available, is cause for considerable concern. This is because of the presence of multiple virus infection, potentially leading to major fruit yield losses and economic hardship to the smallholder farmers that depend on the pepino crop for a living.

Also in the 1970s, another potyvirus was described in the same region infecting the solanaceous crops tomato (S. lycopersicon) and pepper (Capsicum baccatum var. pendulum) and named Peru tomato virus
(PTV) (Fernandez-Northcote and Fulton 1980; Fribourg 1979; Fribourg and Fernandez-Northcote 1982). Phylogenetic analysis using complete genomic sequences of PTV and WPMV confirmed that both were distinct potyviruses (Spetz et al. 2003). This analysis also revealed that they and another potyvirus first found infecting cultivated potato in the Andean highlands of Peru, Potato virus V (PVV) (Fribourg and Nakashima 1984; Jones and Fribourg 1986), were more closely related to each other than to any other potyviruses (Spetz and Valkonen 2003).

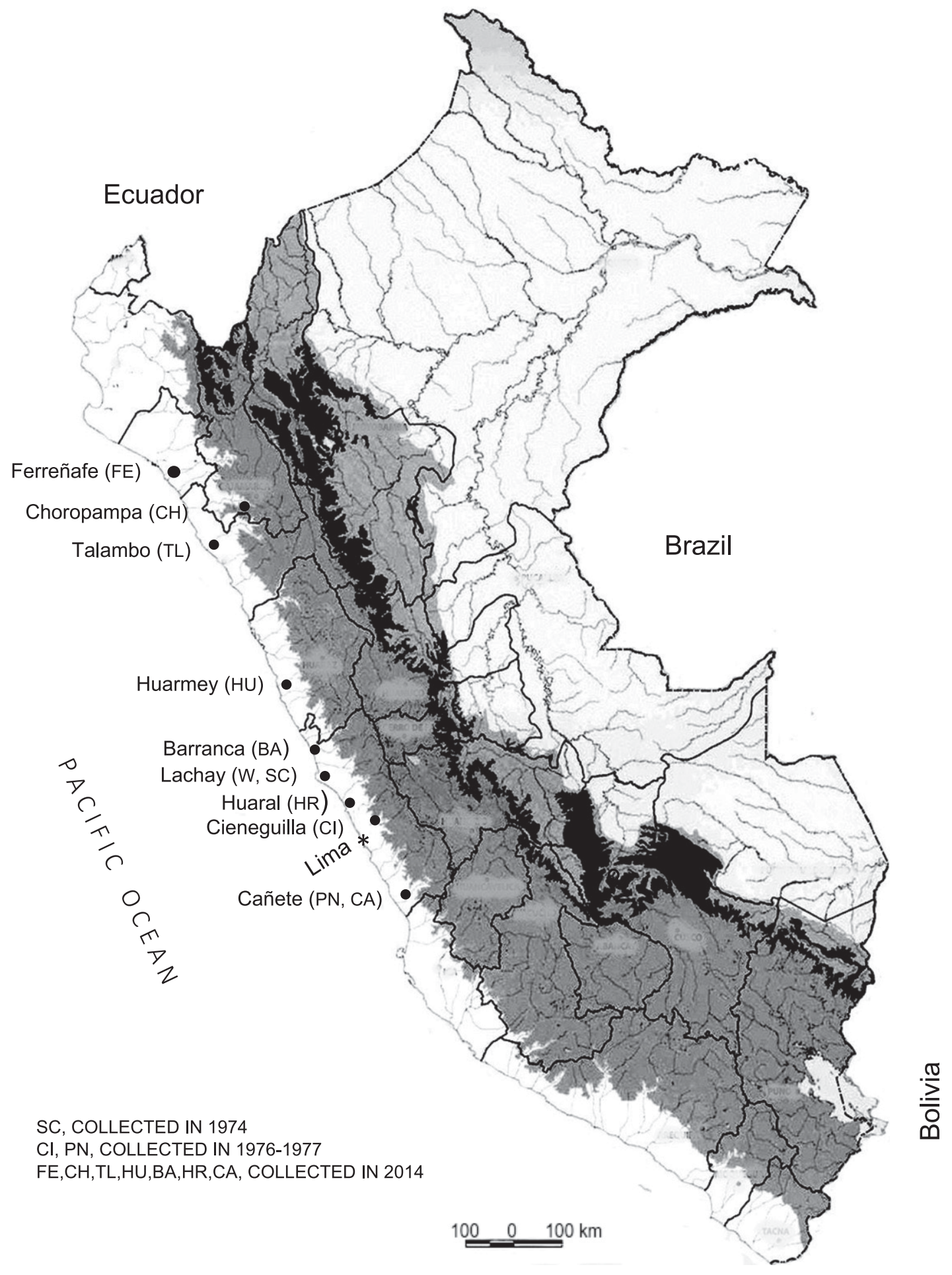

\section{Chile}

Fig. 1. Map of Peru showing the three regions the country is divided into and the collection sites of the 10 Wild potato mosaic virus (WPMV) isolates used in this study. The narrow region on the left is the coastal desert, the central longitudinal region is the Andean highlands, and the Amazon jungle region is on the right. Nine WPMV isolates were collected in the coastal region and a single isolate $(\mathrm{CH})$ in the highlands. 
In 2014, WPMV was isolated again from asymptomatic pepino fruit harvested from plants growing in smallholder fields at six locations in the central and northern coastal regions and one in the northern Andean highlands of Peru. Because WPMV was found in all pepino fruit tested, infection with this virus was apparently very widespread. This article greatly expands knowledge of the host reactions and phylogenetics of this virus, previously based entirely on studies with the WPMV type strain isolated from $S$. chancayense in 1974 (Jones and Fribourg 1979, 1990) or a subsequent subculture of it (Spetz and Valkonen 2003). It describes the biological properties of the pepino isolates and shows that they vary greatly in virulence and, depending on the isolate and host species, infection is sometimes lethal in several solanaceous host species. Using their open reading frame (ORF) sequences, it also determines the phylogenetic relationships between six WPMV isolates from pepino, the type strain from S. chancayense, and the potyviruses PTV and PVV from solanaceous crops in the region.

\section{Materials and Methods}

Plants and mechanical inoculations. Indicator hosts were grown in a sterile mix of soil, peat, and sand (1:1:1). All plants were maintained at 18 to $22^{\circ} \mathrm{C}$ in insect-proof greenhouses located at $\mathrm{La}$ Molina, Lima, Peru. The studies in 1976 to 1978 were undertaken in International Potato Center greenhouses, and those with the seven isolates from pepino in 2014 to $20161 \mathrm{~km}$ away in a National Agrarian University greenhouse. Mechanical inoculations to indicator hosts were made by rubbing cotton swabs dipped in infective leaf sap diluted in distilled water onto leaves previously dusted with 600mesh-sized carborundum powder. Plants of Nicotiana debneyi, $N$. glutinosa, $N$. occidentalis, $N$. rustica, and the cross $N$. bigelovii $\times$ $N$. clevelandii (F1 generation) were used to culture the different WPMV isolates.

Virus isolates. In 1976 to 1977, samples were collected from young leaves of pepino plants showing mosaic and mild rugosity symptoms growing in small, irrigated fields at Cieneguilla in the Lima Valley and Puente Negro in the Canete Valley, both in the central coastal region of Peru (Fig. 1). To obtain virus isolates, sap extracts from these leaf samples were inoculated to $N$. glutinosa plants. No single lesions isolations were attempted. The two potyvirus isolates (CI and PN) that resulted (Table 1) remained unidentified until 2015.

In 2014, symptomless pepino fruit from plants growing in smallholder fields were collected at six locations (Canete, Huaral, Barranca, Huarmey, Talambo, and Ferrenafe) in the central and northern coastal regions and one at Choropampa (Jequetepeque Valley) in the northern Andean highlands $150 \mathrm{~km}$ from the coast. From each location, fruit mesocarp tissue from two ripe fruit was combined and ground in distilled water, and the extract inoculated to leaves of two $N$. occidentalis plants. Once systemic mosaic symptoms developed, leaf tissue from the plant that developed the severest symptoms was desiccated over silica gel and stored for subsequent study in 2015 to 2016 ( 1 isolate/location). The seven isolates obtained in this way were named after each of the locations: CA, HR, BA, HU, TL, FE, and CH (Fig. 1; Table 1). In 2015 to 2016, each of them was reisolated from this desiccated tissue by grinding it in distilled water, followed by inoculation of the sap extract to $N$. occidentalis plants. Then, to eliminate the possibility of mixtures with other viruses, each isolate was passaged through single local lesions in inoculated leaves produced by inoculation of infective $N$. occidentalis sap to Chenopodium quinoa plants. Leaf sap extracts from culture hosts infected with all seven isolates gave positive reactions when tested by enzyme-linked immunosorbent assay (ELISA) using WPMV antiserum.

In 1978, isolate SC-, CI-, and PN-infected leaf samples were dried over silica gel in Peru, sealed in glass vials, and sent to the United Kingdom. Isolate SC was the type strain of WPMV isolated from S. chancayense (Jones and Fribourg 1979). The tin in which these vials were sent currently forms part of the plant virus collection at Fera Science Ltd., York, U.K. In 2016, leaf material containing each of the seven new WPMV isolates from pepino was also dried over silica gel in Peru before sending to Fera Science Ltd.

Serological tests. Serological tests to detect virus infection in plant samples were undertaken using microprecipitin (1976 to 1978) or ELISA (2014 to 2016) tests. Microprecipitin tests were used routinely for serological detection in Peru in the 1970s (Fribourg et al. 1977a,b; Moreira et al. 1980) but, later, direct double-antibody sandwich ELISA was used instead. The procedures employed for these two kinds of standard serological tests were described previously (Ball 1974; Bercks et al. 1972; Clark and Adams 1977). The polyclonal antisera to WPMV type strain (isolate SC), PVS, and PepMV used in these tests were those used previously in La Molina, Lima, Peru (Jones and Fribourg 1979; Jones et al. 1980; Santillan 1979; Santillan et al. 1980).

Symptomatology. In 1977 to 1978, infective leaf sap from N. glutinosa plants infected with isolates CI and PN were inoculated to two plants each of several standard indicator host species frequently used with viruses isolated from solanaceous plants; healthy uninoculated plants of each species were kept as controls. Any virus symptoms that developed were recorded. In 2015 to 2016, the seven recent WPMV isolates were inoculated to healthy plants of (i) the wild potato $S$. chancayense, from which isolate SC originally came (Jones and Fribourg 1979); (ii) five indicator host species previously inoculated with isolates $\mathrm{CI}$ and $\mathrm{PN}$; (iii) five other indicator host species previously inoculated with isolate SC; and (iv) the cross $N$. bigelovii $\times$ $N$. clevelandii. Leaf sap from infected culture plants of $N$. rustica, $N$. occidentalis, or the cross $N$. bigelovii $\times N$. clevelandii was used for these inoculations. Each isolate was inoculated to three plants of each species. Healthy uninoculated plants of each of them were kept as uninfected controls. Any symptoms that developed were

Table 1. Details of Wild potato mosaic virus isolates used in this study

\begin{tabular}{|c|c|c|c|c|c|c|}
\hline Isolate & $\begin{array}{c}\text { Original isolation host } \\
\text { host species }\end{array}$ & $\begin{array}{l}\text { Symptoms in original } \\
\text { isolation host }\end{array}$ & $\begin{array}{c}\text { Where collected or obtained } \\
\text { in Peru }\end{array}$ & $\begin{array}{l}\text { Isolation } \\
\text { year }\end{array}$ & GenBank code & Reference \\
\hline $\mathrm{W}^{\mathrm{b}}$ & Solanum chancayense & Mosaic, leaf deformation (foliage) & Lachay, Chancay Valley (Lomas) & 1974 & AJ437279 & $\begin{array}{l}\text { Spetz and } \\
\quad \text { Valkonen (2003) }\end{array}$ \\
\hline $\begin{array}{l}\text { SC } \\
\text { (Type) }\end{array}$ & S. chancayense & Mosaic, leaf deformation (foliage) & Lachay, Chancay Valley (Lomas) & 1974 & MK092723 & $\begin{array}{l}\text { Jones and } \\
\text { Fribourg (1979) }\end{array}$ \\
\hline CI & S. muricatum & Mosaic, rugosity (foliage) & Cieneguilla, Lima Valley & 1976 & Short sequences & This study \\
\hline $\mathrm{PN}$ & S. muricatum & Mosaic, rugosity (foliage) & Puente Negro, Canete Valley & 1977 & MK092722 & This study \\
\hline $\mathrm{CA}$ & S. muricatum & Symptomless infection (fruit) & Canete, Canete Valley & 2014 & No sequence & This study \\
\hline HR & S. muricatum & Symptomless infection (fruit) & Huaral, Chancay Valley & 2014 & MK092721 & This study \\
\hline BA & S. muricatum & Symptomless infection (fruit) & Barranca, Pativilca Valley & 2014 & MK092720 & This study \\
\hline HU & S. muricatum & Symptomless infection (fruit) & Huarmey, Huarmey Valley & 2014 & No sequence & This study \\
\hline TL & S. muricatum & Symptomless infection (fruit) & Talambo, Jequetepeque Valley & 2014 & MK092724 & This study \\
\hline FE & S. muricatum & Symptomless infection (fruit) & Ferrenafe, Ferrenafe Valley & 2014 & $\begin{array}{l}\text { MK092725, } \\
\text { recombinant }\end{array}$ & This study \\
\hline $\mathrm{CH}$ & S. muricatum & Symptomless infection (fruit) & Choropampa, Jequetepeque Valley & 2014 & No sequence & This study \\
\hline
\end{tabular}

\footnotetext{
${ }^{a}$ Choropampa is located in the Andean highlands of Peru. All the other valleys are located in the country's Pacific coastal region.
}

${ }^{\mathrm{b}}$ Renamed subculture of isolate SC sequenced by Spetz and Valkonen (2003). 
recorded. Samples from inoculated and tip leaves of all hosts were collected 3 weeks after inoculation and tested for WPMV infection by inoculation to two plants of $N$. rustica.

Host species sensitivity and isolate virulence. All nine virus isolates from pepino killed at least one solanaceous host species to which they were inoculated; therefore, induction of plant death from inoculation was used to estimate both host species sensitivity to infection and isolate virulence. Host species killed by many isolates were considered sensitive and those killed by no or one isolate as tolerant. Isolates that killed many host species were considered virulent, whereas those that killed one or no host species were designated avirulent. The phenotypes that developed in the eight hosts inoculated by all seven new pepino isolates (CA, HR, BA, HU, TL, $\mathrm{FE}$, and $\mathrm{CH}$ ) were mainly used for this purpose. The phenotypes that developed in the five solanaceous hosts inoculated solely with $\mathrm{SC}$ and the two old pepino isolates (CI and PN) were less useful, although some information on relevant differences was deduced from them.

Electron microscopy. In 1977, crude sap preparations from isolate CI- and PN-infected leaves of infected plants were mixed with $2 \%$ sodium phosphotungstate ( $\mathrm{pH} 6.5)$ and sprayed onto carboncoated film on copper grids, as described by Roberts (1982). The grids were examined for virus particles using a JEM-100S electron microscope (JEOL USA Ltd.).

High-throughput sequencing. In 2015 to 2017, samples of desiccated WPMV-infected leaf material containing seven isolates (SC, CI, PN, HR, BA, TL, and FE) were subjected to high-throughput sequencing (HTS) (Table 1). For this, total RNA was extracted from each sample using the Plant Total RNA kit (Qiagen or SigmaAldrich), including the optional DNAase treatment. An indexed plant ribosome subtracted sequencing library was then produced from the total RNA using the Scriptseq complete plant leaf kit (Illumina) following the manufacturer's instructions. The indexed library was then sequenced along with others on a MiSeq instrument (Illumina), using a 600 -cycle V3 kit. The resulting paired reads were $3^{\prime}$ trimmed to a quality score of 20 using Sickle in paired-end mode (Joshi and Fass 2011). Contigs were assembled using Trinity v2 at maximum memory allocation of 99 gigabytes of RAM and 64 central processing units allocated to the process (Grabherr et al. 2011). BLAST+ version 2.2.29 was employed to compare the contigs produced to the GenBank nonredundant and nucleotide databases (Camacho et al. 2009). Reads of viral origin were extracted using the extract reads function in MEGAN Community Edition 6.10.2 (Huson et al. 2016). Isolates SC, PN, HR, BA, TL, and FE provided complete WPMV ORFs but isolate CI only two short sequences. No other virus sequences were associated with the complete ORFs of WPMV isolates PN, HR, BA, TL, and FE. However, a yet-to-be identified partitivirus sequence was present with the complete ORF of isolate SC and a CMV sequence with the two short isolate $\mathrm{CI}$ sequences. The six new genomic sequences with complete ORFs were 9,195 nucleotides long, and the two CI sequences were 3,414 and 1,925 nucleotides long. Final nucleotide sequences of the six isolates with complete ORFs were submitted to GenBank with accession numbers MK092720 to MK092725 (Table 1).

Recombination, sequence identities, and phylogenetic analyses. Sequences were edited using BioEdit (Hall 1999). They were aligned using Clustal W in MEGA 7.0.14 (Kumar et al. 2016), MAFFT in Geneious (Katoh and Standley 2013), or the TranslatorX online server using encoded amino acids as a guide and its MAFFT option (Abascal et al. 2010) (http://translatorx.co.uk). The six new complete WPMV ORF sequences were aligned with the isolate W (AJ437279) sequence and this alignment was searched for evidence of genetic recombination using the full suite of options in RDP4 with default parameters (Boni et al. 2007; Gibbs et al. 2000; Holmes et al. 1999; Lemey et al. 2009; Martin and Rybicki 2000; Martin et al. 2005, 2015; Maynard Smith 1992; Padidam et al.1999; McGuire and Wright 2000; Posada and Crandall 2001). Isolate $\mathrm{W}$ had been derived from a Scottish subculture of original WPMV type isolate SC, and subsequently renamed isolate W prior to sequencing (Spetz and Valkonen 2003; Spetz et al. 2003). Percentage nucleotide identities between genomes were calculated using a matrix of nucleotide identities produced using Sequence Demarcation tool v1 (Muhire et al. 2014).

Mega 7 (Kumar et al. 2016) was used to determine the most appropriate replacement models for computing maximum-likelihood (ML) trees of complete nucleotide ORFs and their encoded amino acid sequences. The BlastN and BlastP online facilities of GenBank (Altschul et al. 1990) were used to search for sequences related to WPMV. Phylogenetic trees were calculated using PhyML 3.0 (Guindon and Gascuel 2003). Statistical support for their nodes was calculated by the SH method (Shimodaira and Hasegawa 1999). Trees were drawn using Figtree 1.4.2 (http://tree.bio.ed.ac.uk/software/figtree/) and a commercial computer illustration package.

The ML tree calculated from nucleotide sequences was rooted using the midpoint option in Figtree. It compared the ORFs of the five nonrecombinant WPMV isolates with those of six PVV sequences and two sequences of PTV (synonym Peru tomato mosaic virus [PTMV]; AJ437280 and AJ516010). The outgroups consisted of the ORFs of single sequences of Mashua virus $Y$ (MH680824) (Adams et al. 2018b), Brugmansia mosaic virus (JX874139) (Damsteegt et al. 2013), and Pepper mottle virus (EU586121) (Kim et al. 2009). The ML tree calculated from encoded amino acid sequences compared the main ORFs of single representative, mostly complete genomes of 27 members of the $\mathrm{Po}$ tato virus $Y$ (PVY) lineage found in GenBank in October 2018. For this, two WPMV ORFs, those of MK092723 (SC) and MK092722 $(\mathrm{PN})$, were used to search the GenBank database, and the full genomic sequences of closely related potyviruses were identified and downloaded. Their ORFs were aligned with those of all five complete nonrecombinant WPMV isolates. The alignment also included partial sequences of closely related potyviruses, consisting mostly of their NIb plus coat protein sequences. The positions and relative branch lengths of these partial sequences were calculated using only those regions shared by the partial and complete polyprotein sequences.

\section{Results}

Isolate purity. In 1977, electron microscopy was used to examine leaf sap extracts from $N$. debneyi and $N$. rustica plants infected with isolates $\mathrm{CI}$ and $\mathrm{PN}$, respectively. In both instances, flexuous filamentous virions $750 \mathrm{~nm}$ in length typical of potyviruses were present but no other virions were recorded. Microprecipitin tests on leaf sap extracts from the infected $N$. glutinosa plants failed to detect PepMV. Similarly, no evidence of another virus being present was found when sap extracts containing isolate SC were examined in the electron microscope, tested serologically, or inoculated to indicator hosts (Jones and Fribourg 1979). However, when HTS was used with these three isolates, in addition to WPMV sequences, the presence of $\mathrm{CMV}$ and partitivirus sequences was revealed with isolates $\mathrm{CI}$ and $\mathrm{SC}$, respectively (see above).

All seven new isolates that were passaged through single local lesions provided cultures that gave a positive reaction when extracts of samples from their infected leaves were tested by ELISA using WPMV antiserum. However, they were free from CMV, PepMV, and ToMV for several reasons. Inoculation of indicator hosts with infective $N$. occidentalis sap never caused any phenotypic reactions typical of these viruses in any indicator host. For example, none of them ever induced any local lesions in inoculated leaves of $N$. glutinosa (ToMV indicator host) (Hollings and Huttinga 1976) or Vigna unguiculata (CMV indicator host) (Francki et al. 1979), or any local or systemic symptoms in Datura stramonium (PepMV indicator host) (Jones et al. 1980). Also, none of them induced the systemic mottle in $C$. quinoa plants typical of $\mathrm{PVS}^{\mathrm{A}}$ (Hinostroza-Orihuela 1973; Santillan et al. 1980, 2018), and HTS did not reveal any admixture with other viruses (see above).

Symptomatology. All isolates from pepino infected the indicator host plants inoculated with them (Table 2) but there was considerable variation in the symptom types and severities they elicited (Table 2; Fig. 2). In contrast, isolate SC failed to infect C. quinoa and N. glutinosa. In $N$. rustica, all nine pepino isolates resembled isolate $\mathrm{SC}$ in inducing chlorotic or necrotic local lesions (Fig. 2A) and systemic 
chlorotic or necrotic spots, blotches, or rings (Fig. 2B, left and right) but BA also induced plant death. In N. tabacum 'Samsun', isolates CI and $\mathrm{HU}$ resembled isolate $\mathrm{SC}$ in inducing asymptomatic infection in inoculated leaves instead of the local necrotic lesions elicited by the other seven isolates. Systemic necrotic rings were induced in this host by five pepino isolates and isolate SC (Fig. 2C, left) but not by $\mathrm{CI}$, $\mathrm{PN}, \mathrm{HR}$, and HU. In addition, except with isolates SC, CI, and PN, veinal necrosis (Fig. 2C, right) was recorded for all isolates, which extended to the petioles and stems with isolates CA, HR, and HU (Fig. 2D). In the F1 cross $N$. bigelovii $\times N$. clevelandii, all seven

Table 2. Symptoms caused by nine Wild potato mosaic virus isolates in indicator hosts and Solanum chancayense

\begin{tabular}{|c|c|c|c|c|c|c|c|c|c|c|}
\hline \multirow[b]{2}{*}{ Host, infection } & \multicolumn{10}{|c|}{ Isolate $^{a}$} \\
\hline & SC & CI & PN & CA & HR & $\mathbf{B A}$ & HU & TL & FE & $\mathbf{C H}$ \\
\hline \multicolumn{11}{|l|}{$\begin{array}{l}\text { Chenopodium } \\
\text { quinoa }\end{array}$} \\
\hline Local & $\mathrm{NI}$ & NS & NS & CS, NS & CS NS & NS & $\mathrm{CS}, \mathrm{NS}$ & NS & NS & NS \\
\hline Systemic & NI & NI & NI & 0 & 0 & 0 & CS, NS & 0 & 0 & NS \\
\hline \multicolumn{11}{|l|}{$\begin{array}{l}\text { Nicandra } \\
\text { physaloides }\end{array}$} \\
\hline Local & 0 & $\ldots$ & $\ldots$ & CS & CS & NS & NS & CS & CS & NS \\
\hline Systemic & M & $\ldots$ & $\ldots$ & $\begin{array}{l}\text { VC, CS, } \\
\text { UCTL, M }\end{array}$ & $\begin{array}{l}\text { VC, CS, } \\
\text { UCTL, } \\
\text { M, LDr }\end{array}$ & $\begin{array}{c}\text { VC, CS, } \\
\text { NS, LEp, } \\
\text { GN, PD }\end{array}$ & $\begin{array}{c}\text { VC, LEp, } \\
\text { UCTL, GN, } \\
\text { PD }\end{array}$ & $\begin{array}{l}\text { VC, LEp, } \\
\text { UCTL }\end{array}$ & $\begin{array}{l}\text { VC, LEp } \\
\text { UCTL }\end{array}$ & $\begin{array}{c}\text { VC, NS, } \\
\text { LEp, UCTL }\end{array}$ \\
\hline \multicolumn{11}{|l|}{$\begin{array}{l}\text { Nicotiana } \\
\text { benthamiana }\end{array}$} \\
\hline Local & 0 & $\ldots$ & $\ldots$ & $\mathrm{CS}$ & $\mathrm{CS}$ & $\mathrm{CS}$ & $\mathrm{CS}$ & $\mathrm{CS}$ & $\mathrm{CS}$ & NS, NR \\
\hline Systemic & 0 & $\ldots$ & $\ldots$ & $\begin{array}{c}\text { VC, LEp, } \\
\text { M, GN, } \\
\text { PD }\end{array}$ & $\begin{array}{l}\text { VC, LEp, } \\
\text { M, GN, } \\
\text { PD }\end{array}$ & $\begin{array}{l}\text { VC, LEp, } \\
\text { M, GN, } \\
\text { PD }\end{array}$ & $\begin{array}{l}\text { VC, LEp, } \\
\text { M, GN, } \\
\text { PD }\end{array}$ & $\begin{array}{l}\text { VC, LEp, } \\
\text { M, GN, } \\
\text { PD }\end{array}$ & $\begin{array}{l}\text { VC, LEp, } \\
\text { M, GN, } \\
\text { PD }\end{array}$ & $\begin{array}{c}\text { VC, VN, LEp, } \\
\text { GN, PD }\end{array}$ \\
\hline \multicolumn{11}{|l|}{ N. bigelovii } \\
\hline Local & 0 & NS & 0 & $\ldots$ & $\ldots$ & $\ldots$ & $\ldots$ & $\ldots$ & $\ldots$ & $\ldots$ \\
\hline Systemic & $\mathrm{M}, \mathrm{LDf}$ & $\begin{array}{c}\text { VC, M, LDf, } \\
\text { GN, PD }\end{array}$ & VC LSr-M & $\ldots$ & $\ldots$ & $\ldots$ & $\cdots$ & $\ldots$ & $\cdots$ & $\ldots$ \\
\hline \multicolumn{11}{|l|}{$\begin{array}{c}\text { F1 } N . \text { bigelovii } \times \\
N . \text { clevelandii }\end{array}$} \\
\hline Local & $\ldots$ & $\ldots$ & $\ldots$ & $\mathrm{CS}$ & $\mathrm{CS}$ & $\mathrm{CS}, \mathrm{CR}$ & CS & CS, NS & 0 & $\mathrm{CS}, \mathrm{CR}$ \\
\hline Systemic & $\cdots$ & $\ldots$ & $\ldots$ & $\begin{array}{c}\text { VC, NS, M, } \\
\text { LCr, LSr }\end{array}$ & $\mathrm{VC}, \mathrm{M}, \mathrm{LSr}$ & $\begin{array}{l}\mathrm{VC}, \mathrm{M}, \\
\mathrm{LCr}, \mathrm{LSr}\end{array}$ & $\mathrm{M}, \mathrm{LCr}$ & $\mathrm{M}, \mathrm{LCr}$ & $\mathrm{M}, \mathrm{LCr}$ & $\begin{array}{l}\mathrm{VC}, \mathrm{NS}, \\
\mathrm{M}, \mathrm{LSr}\end{array}$ \\
\hline \multicolumn{11}{|l|}{ N. clevelandii } \\
\hline Local & 0 & NS & NS, NR & $\ldots$ & $\ldots$ & $\ldots$ & $\ldots$ & $\ldots$ & $\ldots$ & $\ldots$ \\
\hline Systemic & M & $\begin{array}{c}\text { NS, M, } \\
\text { LDf, LD, } \\
\text { GN, PD }\end{array}$ & $\begin{array}{l}\text { VC, NS, } \\
\text { LD, GN, } \\
\text { PD }\end{array}$ & $\ldots$ & $\ldots$ & $\ldots$ & $\ldots$ & $\ldots$ & $\cdots$ & $\ldots$ \\
\hline \multicolumn{11}{|l|}{ N. debneyi } \\
\hline Local & 0 & 0 & CS & $\ldots$ & $\ldots$ & $\ldots$ & $\ldots$ & $\ldots$ & $\ldots$ & $\ldots$ \\
\hline Systemic & 0 & VC, LSr-M & LSr-M & $\ldots$ & $\ldots$ & $\ldots$ & $\ldots$ & $\ldots$ & $\ldots$ & $\ldots$ \\
\hline \multicolumn{11}{|l|}{ N. glutinosa } \\
\hline Local & NI & 0 & 0 & $\ldots$ & $\ldots$ & $\ldots$ & $\ldots$ & $\ldots$ & $\ldots$ & $\ldots$ \\
\hline Systemic & NI & VC, LSr-M & VC, LSr-M & $\ldots$ & $\ldots$ & $\ldots$ & $\ldots$ & $\ldots$ & $\ldots$ & $\ldots$ \\
\hline \multicolumn{11}{|l|}{ N. occidentalis } \\
\hline Local & 0 & NS & NS & NS & NS & NS & NS & CS & CS & NS \\
\hline Systemic & $\begin{array}{l}\text { VC, M, } \\
\text { UCTL }\end{array}$ & $\begin{array}{l}\text { LDr, GN, } \\
\text { PD }\end{array}$ & VC, LSr-M & $\mathrm{VC}, \mathrm{M}$ & VC, NS, M & $\mathrm{VC}, \mathrm{NS}, \mathrm{M}$ & $\begin{array}{l}\mathrm{VC}, \mathrm{NS} \\
\mathrm{M}, \mathrm{LCr}\end{array}$ & $\mathrm{VC}, \mathrm{M}$ & $\mathrm{VC}, \mathrm{M}$ & $\begin{array}{l}\text { VC, NS, } \\
\text { M, LCr }\end{array}$ \\
\hline \multicolumn{11}{|l|}{ N. rustica } \\
\hline Local & $\mathrm{CB}, \mathrm{NR}$ & NR & NR & CS & NS & NS & NS, NR & $\mathrm{CS}$ & CS & CS \\
\hline Systemic & $\mathrm{CB}, 0$ & $\mathrm{VC}, \mathrm{CS}$ & $\mathrm{VC}, \mathrm{CS}, 0$ & $\begin{array}{c}\text { VC, CS, } \\
\text { CR, LCr, M }\end{array}$ & $\begin{array}{l}\text { VC, CS, } \\
\mathrm{NB}, \mathrm{LCr}\end{array}$ & $\begin{array}{l}\mathrm{VC}, \mathrm{NS}, \\
\mathrm{CB}, \mathbf{P D}\end{array}$ & $\mathrm{VC}, \mathrm{CS}, \mathrm{NB}$ & $\begin{array}{l}\mathrm{VC}, \mathrm{CR} \\
\mathrm{CB}, \mathrm{M}\end{array}$ & $\begin{array}{l}\mathrm{VC}, \mathrm{CR} \\
\mathrm{CB}, \mathrm{M}\end{array}$ & $\begin{array}{l}\mathrm{VC}, \mathrm{CS}, \\
\mathrm{LCr}\end{array}$ \\
\hline \multicolumn{11}{|l|}{ N. tabacum } \\
\hline Local & 0 & 0 & NS & NS, NR & NS, NR & NS & 0 & NS, NR & NS, NR & NS, NR \\
\hline Systemic & NS, NR, CB & M & $\mathrm{VC}, \mathrm{M}$ & $\begin{array}{l}\text { VC, VN, NB, } \\
\text { INR, SN }\end{array}$ & $\begin{array}{l}\mathrm{VC}, \mathrm{VN}, \\
\mathrm{NB}, \mathrm{SN}\end{array}$ & VN, INR & $\begin{array}{l}\mathrm{VC}, \mathrm{VN}, \\
\mathrm{NB}, \mathrm{SN}\end{array}$ & $\begin{array}{l}\text { VC, NB, } \\
\text { VN INR }\end{array}$ & $\begin{array}{l}\mathrm{VC}, \mathrm{VN} \\
\mathrm{NB}, \mathrm{INR}\end{array}$ & $\begin{array}{l}\mathrm{VC}, \mathrm{VN}, \\
\mathrm{NB}, \mathrm{INR}\end{array}$ \\
\hline \multicolumn{11}{|c|}{ Physalis floridana } \\
\hline Local & 0 & $\ldots$ & $\ldots$ & 0 & 0 & 0 & 0 & 0 & 0 & 0 \\
\hline Systemic & M & $\ldots$ & $\ldots$ & $\begin{array}{l}\text { VC, LEp, } \\
\text { LDr }\end{array}$ & VC, LEp, LDr & $\begin{array}{l}\text { VC, LEp, } \\
\text { GN, PD }\end{array}$ & $\begin{array}{l}\text { VC, LEp, } \\
\text { GN, PD }\end{array}$ & $\begin{array}{l}\text { VC, LEp, } \\
\text { GN, PD }\end{array}$ & $\begin{array}{l}\text { VC, LEp, } \\
\text { GN, PD }\end{array}$ & $\begin{array}{l}\text { VC, LEp, } \\
\text { GN, PD }\end{array}$ \\
\hline \multicolumn{11}{|l|}{$\begin{array}{l}\text { Solanum } \\
\text { chancayense }\end{array}$} \\
\hline Local & 0 & $\ldots$ & $\ldots$ & $\begin{array}{l}\text { NS, LCl, } \\
\text { LDr }\end{array}$ & $\mathrm{LCl}, \mathrm{LDr}$ & $\begin{array}{l}\mathrm{NS}, \mathrm{LCl} \\
\text { LDr }\end{array}$ & $\begin{array}{l}\mathrm{CS}, \mathrm{LCl} \\
\mathrm{LDr}\end{array}$ & $\begin{array}{l}\mathrm{CS}, \mathrm{LCl}, \\
\text { LDr }\end{array}$ & $\begin{array}{c}\mathrm{CS}, \mathrm{LCl} \\
\mathrm{LDr}\end{array}$ & $\begin{array}{l}\mathrm{NS}, \mathrm{LCl} \\
\text { LDr }\end{array}$ \\
\hline Systemic & $\mathrm{M}, \mathrm{LDf}$ & $\ldots$ & $\ldots$ & $\begin{array}{l}\text { LEp, LCl, LN, } \\
\text { LSr-M, LDf }\end{array}$ & $\begin{array}{l}\text { LEp, LSr-M, } \\
\text { SN, PD }\end{array}$ & $\begin{array}{l}\text { LCl, LN, } \\
\text { SN, PD }\end{array}$ & $\begin{array}{l}\text { LEp, LCl, } \\
\text { SN, PD }\end{array}$ & $\begin{array}{l}\text { LEp, LCl, } \\
\text { LSr-M, LDf }\end{array}$ & $\begin{array}{l}\text { LEp, LCl, } \\
\text { LSr-M, LDf }\end{array}$ & $\begin{array}{l}\text { LEp, LCl, } \\
\text { LN, PD }\end{array}$ \\
\hline
\end{tabular}

a Data for isolate SC (= type strain) from Jones and Fribourg (1979); studies undertaken in 1975 to 1978 (SC, CI, and PN) or 2015 to 2016 (other seven isolates). Coded symptom descriptions: $\mathrm{CB}=$ chlorotic blotches, $\mathrm{CS}=$ chlorotic spots, $\mathrm{CR}=$ chlorotic rings, $\mathrm{GN}=$ generalized necrosis, INR $=$ interrupted necrotic rings, $\mathrm{LCr}=$ leaf crinkling, $\mathrm{LCl}=$ leaf chlorosis, $\mathrm{LEp}=$ leaf epinasty, $\mathrm{LD}=$ leaf death, $\mathrm{LDf}=$ leaf deformation, $\mathrm{LDr}=$ leaf drop, $\mathrm{LN}=$ leaf necrosis, $\mathrm{LSr}=$ leaf size reduction, $\mathrm{LSr}-\mathrm{M}=$ leaf size reduction and mosaic of top leaves, $\mathrm{M}=$ mosaic, $\mathrm{NB}=$ necrotic blotches, $\mathrm{NI}=$ not infected, $\mathrm{NR}=$ necrotic rings, $\mathrm{NS}=$ necrotic spots, PD (in bold) = plant death, $\mathrm{SN}=$ stem necrosis, UCTL = upward curling of top leaves, VC = vein clearing, VN $=$ vein necrosis, and $0=$ symptomless infection. 
new pepino isolates caused mosaic (Fig. 2E) but $\mathrm{CA}$ and $\mathrm{CH}$ also produced necrotic spots and smaller-sized top leaves. Except for $\mathrm{CH}$, which caused necrotic spots or rings (Fig. 2I, left) and SC, which caused symptomless infection, the remaining six new pepino isolates all induced chlorotic spots in inoculated leaves of $N$. benthamiana. In addition, in contrast to SC, which was asymptomatic, all seven of them caused systemic necrosis (Fig. 2I, right) followed by plant death. In Physalis floridana, with the sole exception of SC, which induced mosaic, all seven isolates tested elicited systemic vein clearing and leaf epinasty. Also, apart from SC, CA, and $\mathrm{HR}$, all of them caused systemic necrosis and plant death. Seven isolates caused local necrotic spots in N. occidentalis (Fig. 2F) but, with TL and FE, the lesions were only chlorotic and, with $\mathrm{SC}$, infection was asymptomatic in inoculated leaves. In addition, apart from CI, all isolates caused systemic vein clearing but $\mathrm{HR}$, $\mathrm{BA}, \mathrm{HU}$, and $\mathrm{CH}$ also induced systemic necrotic spots (Fig. 2G, left) which spread irregularly, causing leaf crinkling in plants infected with $\mathrm{HU}$ and $\mathrm{CH}$ (Fig. 2G, right). All seven new pepino isolates induced systemic vein clearing in Nicandra physaloides but varied in the other types of symptoms they elicited. For example, SC, CA, and HR failed to induce epinasty of middle leaves, only $\mathrm{SC}$ and $\mathrm{BA}$ failed to induce characteristic upward curling of top leaves (Fig. 2J), and only BA and HU caused plant death; SC only induced mosaic. Except with SC, which failed to infect $C$. quinoa, all isolates induced local chlorotic or necrotic spots in this species (Fig. 2H), and all seven new pepino isolates caused systemic infection that was mostly asymptomatic; however, $\mathrm{HU}$ and $\mathrm{CH}$ induced systemic necrotic spotting. When the additional species $S$.
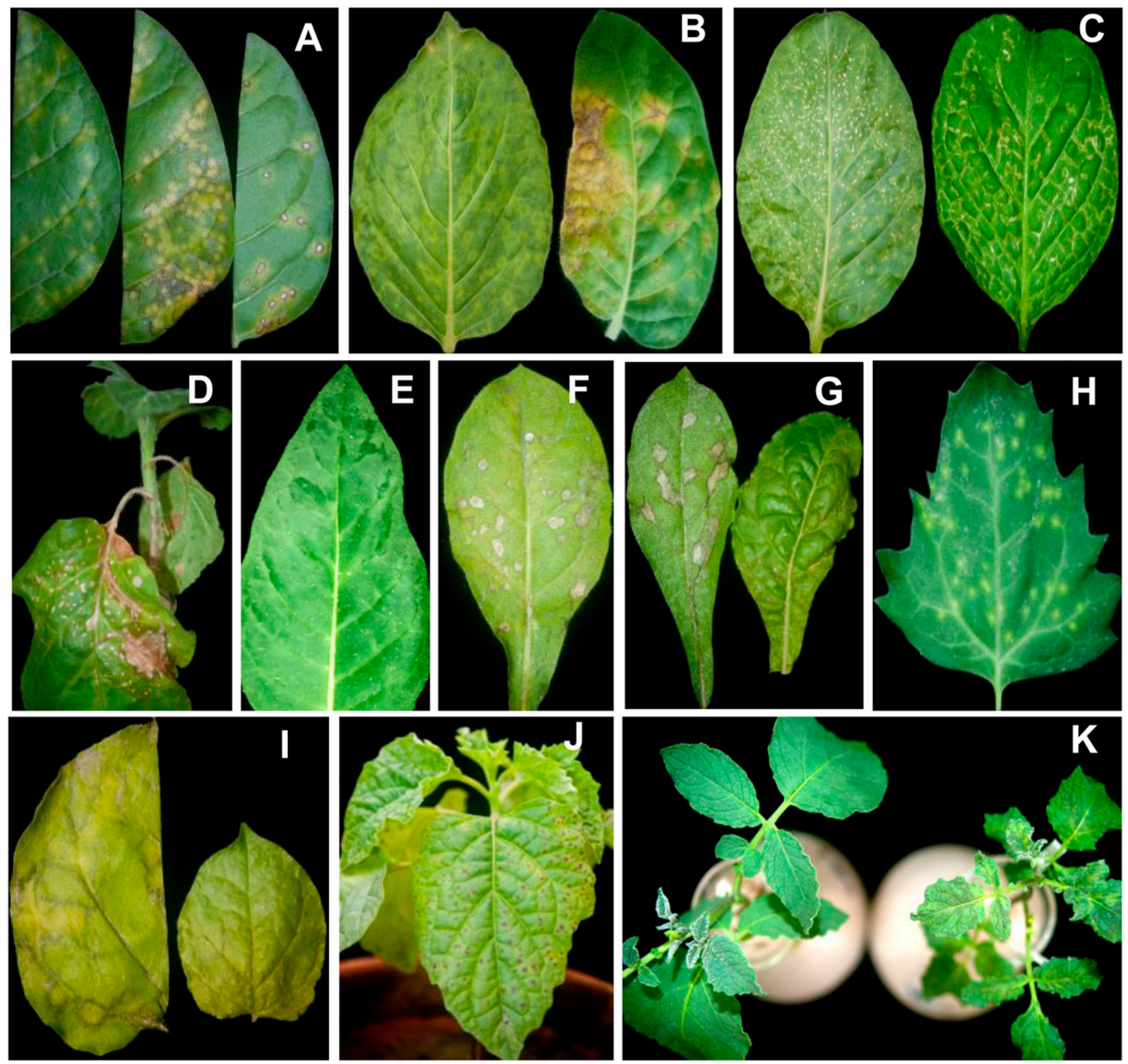

Fig. 2. Symptoms produced in leaves and plants of indicator hosts caused by infection with different Wild potato mosaic virus isolates. A, Left to right: Local chlorotic spots, local chlorotic spots surrounded with necrotic rings, and local necrotic spots in inoculated leaves of Nicotiana rustica caused by infection with isolates $\mathrm{CH}$, $\mathrm{HU}$, and BA, respectively. B, Left to right: Systemic chlorotic rings and systemic necrotic spots surrounded by chlorotic areas in N. rustica caused by infection with isolates TL and BA, respectively. C, Left to right: Systemic necrotic interrupted rings and systemic vein necrosis in N. tabacum 'Samsun' caused by infection with isolates CA and HR, respectively. D, Systemic vein, petiole, and stem necrosis in N. tabacum 'Samsun' caused by infection with isolate HU. E, Systemic mosaic in F1 cross of N. bigelovii × N. clevelandii caused by infection with isolate TL. F, Irregular local necrotic spots in inoculated leaves of $N$. occidentalis caused by infection with isolate CA. G, Left to right: Systemic necrotic spots and leaf crinkling in N. occidentalis caused by infection with isolate CH. H, Local chlorotic spots in inoculated leaves of Chenopodium quinoa caused by infection with isolate HU. I, Left to right: Local necrotic rings in inoculated leaves and systemic vein necrosis in $\mathrm{N}$. benthamiana caused by infection with isolate $\mathrm{CH}$. J, Systemic necrotic spots, leaf epinasty of middle leaves, and upward curling of top leaves in Nicandra physaloides caused by infection with isolate CH. K, Reduced leaf size, mosaic, and deformation of top leaves in Solanum chancayense caused by infection with isolate $\mathrm{TL}$ (left, healthy plant). 
pimpinellifolium was inoculated with isolates $\mathrm{SC}, \mathrm{CI}$, and $\mathrm{PN}, \mathrm{SC}$ failed to infect it, a systemic mosaic developed with CI, and PN caused local necrotic ring and spot lesions without systemic invasion.

Isolate $\mathrm{SC}$ and the seven new pepino isolates all invaded S. chancayense systemically. SC induced asymptomatic infection in inoculated leaves whereas the new isolates all induced chlorosis and leaf drop, which was accompanied by chlorotic or necrotic local lesions, with all except isolate HR. All of these isolates except BA, HU, and $\mathrm{CH}$ induced a systemic mosaic; all except $\mathrm{SC}$ and BA caused leaf epinasty; and all except SC and HR caused leaf chlorosis of middle leaves. Reduction in leaf size and mosaic developed with CA, HR, TL, and FE (Fig. 2K, right) and, with HR, BA, HU, and CH, systemic infection caused plant death.

With isolate CI, there was no evidence of CMV contamination among the phenotypic responses obtained with this isolate (Table 2). Possibly the CI culture became contaminated after the host inoculations were done. Alternatively, the CMV isolate present might have come from mixed infection in the original pepino sample that CI came from but was asymptomatic in the hosts inoculated. Similarly, from the phenotypic responses obtained, there was no evidence of partitivirus contamination in the SC culture. This is expected because partitivirus infection rarely causes disease symptoms in plants, apparently also including when mixed infection occurs with other viruses (Roossinck 2010).

Isolate virulence. When induction of plant death in hosts was used as a measure of isolate virulence, the most virulent isolate was BA because it caused plant death in five of eight solanaceous hosts inoculated with it. HU killed four of eight; thus, it was also relatively virulent. The mildest isolate was SC because it failed to kill any of these solanaceous hosts or the four others it was inoculated to. CA was also mild because it only killed one of eight solanaceous hosts. Isolates $\mathrm{HR}, \mathrm{TL}, \mathrm{FE}$, and $\mathrm{CH}$ were of intermediate virulence because each killed two to three of the eight solanaceous hosts inoculated with them. Isolates CI and PN killed one or three of the six solanaceous hosts they were inoculated with, respectively; thus, CI seemed relatively virulent and $\mathrm{PN}$ of relatively low virulence.

Host species sensitivity. Using plant death as a measure of host species sensitivity to infection, Nicotiana benthamiana was highly

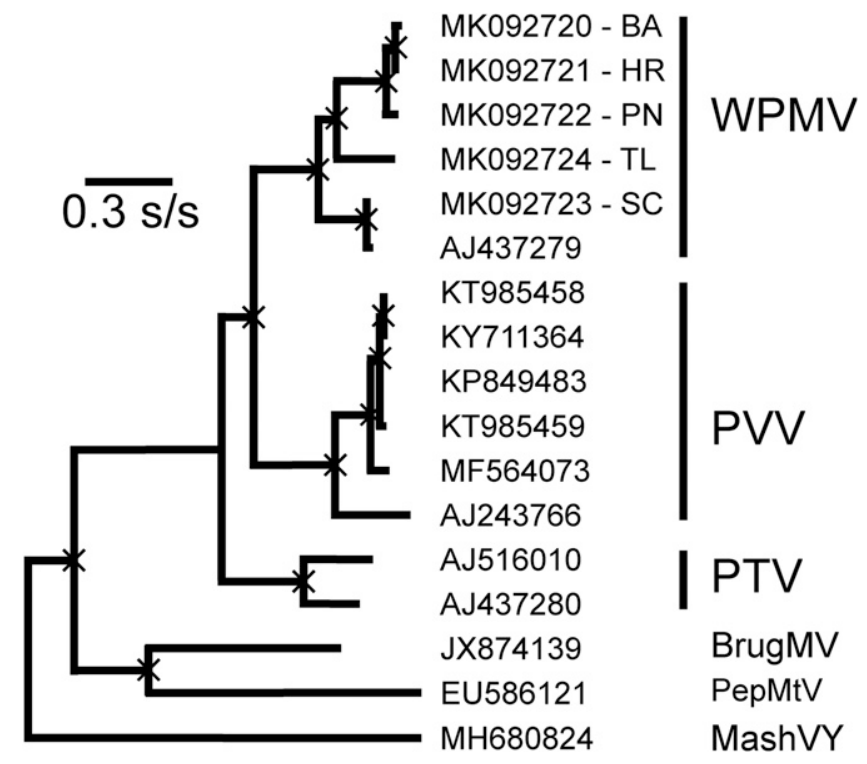

Fig. 3. Maximum-likelihood phylogeny of the nonrecombinant open reading frame (ORF) sequences of six isolates of Wild potato mosaic virus (WPMV), together with those of six of Potato virus V (PVV) and two of Peru tomato virus (PTV; synonym Peru tomato mosaic virus) with three outgroup sequences. Nodes marked with a cross had $>0.90 \mathrm{SH}$ support. The outgroup consisted of the ORFs of single sequences of Mashua virus Y (MashVY; MH680824), Brugmansia mosaic virus (BrugMV; JX874139), and Pepper mottle virus (PepMtV; EU586121). Midpoint root calculated by Figtree. The same root was found using the amino acid sequences of the same sequences. sensitive because it was killed by all seven new pepino isolates (Table 2). SC was the only isolate that failed to kill it, its systemic infection being asymptomatic. P. floridana and S. chancayense were also sensitive because they were each killed by four to five of these seven isolates. In contrast, none of the 10 isolates killed $C$. quinoa or $N$. tabacum; thus, these were the most tolerant hosts. $N$. rustica and $N$. occidentalis also seemed tolerant because only 1 each of the 10 isolates killed them. Nicandra physaloides was killed by two of the new isolates. Among the four solanaceous hosts only inoculated with $\mathrm{SC}$ and the two old pepino isolates (CI and $\mathrm{PN})$, none of the isolates killed Nicotiana debneyi or N. glutinosa. However, although none of the seven new isolates killed the F1 generation of the $N$. bigelovii $\times N$. clevelandii cross, with its parents, both $\mathrm{CI}$ and PN killed N. clevelandii and CI killed $N$. bigelovii.

Recombination. The ORF of MK092725 (FE) was identified as likely recombinant having as its major parent MK092722 (PN) and minor parent uncertain, perhaps MK092724 (TL), between nucleotides 5,434 and 6,571 and detected by six methods, with probabilities ranging from $6 \times 10^{-3}$ to $7 \times 10^{-9}$. The other recombinant identified was PVV isolate KC433411 (KER.LAL.P) (Shamsadden-Saeed et al. 2014), a definitive recombinant between two PVV isolates; its major parent AJ243766 and minor parent KT985458 between nucleotides 160 and 1,105 were detected by six methods with probabilities ranging from $6 \times 10^{-3}$ to $8 \times 10^{-16}$. The two recombinants were removed from the subsequent phylogenetic analyses.

Sequence identities. In pairwise comparisons, the complete ORF sequences of the six new complete WPMV genomes (SC, PN, HR, BA, TL, and FE) were compared with that of previously sequenced isolate W (Table 1). They had nucleotide identities of 80.9 to $99.8 \%$, whereas the most closely related virus, PVV, had ORFs around $75 \%$ identical. The WPMV type isolate SC (MK092723) and isolate W (AJ437279) differed by only 18 nucleotides over their entire 9,195-nucleotide lengths.

Phylogenetic analysis. The WPMV and PVV isolates fell into two statistically separate clusters (Fig. 3). PTV and PTMV formed a similar third cluster and appeared as two isolates of a single virus. Except within the PVV cluster, all nodes had $>0.92 \mathrm{SH}$ support. There was no obvious relationship between the phylogenetic distance between individual WPMV isolates (Fig. 3) and the geographical distances between their collection sites (Fig. 1). For example, the type isolate $\mathrm{SC}$ was the most phylogenetically distinct from all the others, apart from W. Like three of the four other nonrecombinant WPMV sequences, it came from an isolate collected in central coastal Peru. However, the sequence which was closest to it in the tree (TL) was of an isolate from north coastal Peru. When the two regions of the incomplete $\mathrm{CI}$ isolate genome were aligned separately from the others and ML trees were calculated, both placed the CI sequence between those of the PN and TL isolates.

An ML taxonomy calculated from encoded amino acid sequences in which all nodes marked with a cross had $>0.90 \mathrm{SH}$ support is shown in Figure 4. The PVY lineage had two main sublineages, the most speciose of which included PVY itself and some viruses that infect nonsolanaceous plants, notably members of the Compositae family. The lesser sublineage included WPMV, PVV, PTV, and six others all originally isolated from solanaceous plants in the Americas. Within this sublineage, Ecuadorian rocoto virus grouped with WPMV, PVV, and PTV. Pepper mottle virus, Brugmansia mosaic virus, and Brugmansia suaveolens virus formed a second group and Pepper yellow mosaic virus and Tobacco mosqueado virus a third. All except 2 of the 27 viruses of the overall PVY lineage were originally isolated in the Americas.

\section{Discussion}

For more than 40 years, WPMV was considered a wild plant virus of no economic significance. However, our research suggests this assumption is likely to be incorrect. Here, we demonstrate for the first time that WPMV not only infects wild potato plants growing in Peru's coastal desert region but also is able to infect irrigated solanaceous crop plants commonly planted there, in this case the vegetatively propagated fruit crop pepino. Presumably, this virus 
evolved first in the Lomas vegetation and spread later to the pepino crop after its initial domestication in the Andean region and its subsequent planting in irrigated coastal desert fields in close proximity to natural vegetation. In 2014, it was isolated from all pepino fruit samples collected from widely dispersed locations in Peru, suggesting that infection occurs commonly in this crop in different parts of the country. Also, although the original type isolate of this virus from $S$. chancayense mostly caused mild symptoms in standard solanaceous indicator hosts, this was not necessarily so for the WPMV isolates from pepino. Indeed, although infection with the type isolate was never lethal in any host tested, all pepino isolates inoculated to $N$. benthamiana plants killed this species and more than half of them killed plants of $P$. floridana and the wild potato species $S$. chancayense. Moreover, the individual WPMV isolates tested varied greatly in virulence, and the solanaceous hosts tested varied considerably in their sensitivity to infection. Because the pepino crop is already known to become infected with at least four other viruses in coastal Peru, depends entirely on local land races, and is vegetatively propagated in the complete absence of any healthy stock program, the finding of apparently widespread infection with a fifth virus (WPMV) suggests the likelihood of considerable virus disease-induced losses in its fruit production due to multiple virus infection. In addition, including the six new WPMV genomes obtained in phylogenic analyses revealed no evidence of any relationship between the phylogenetic distance between individual WPMV isolates and the geographical distances between their original

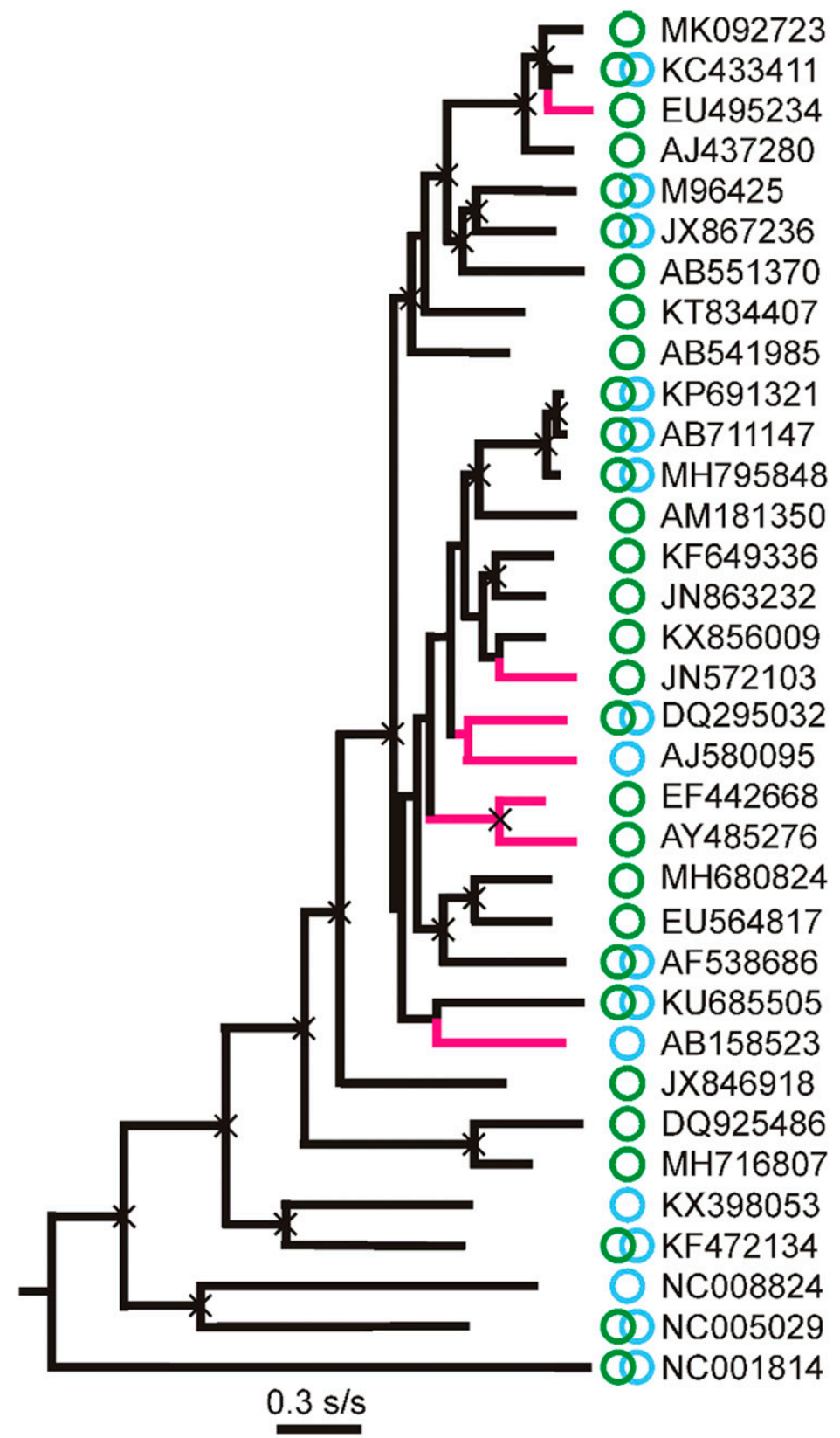

Wild potato mosaic virus

Potato virus $\mathrm{V}$

Ecuadorian rocoto virus

Peru tomato mosaic virus

Pepper mottle virus

Brugmansia mosaic virus

Brugmansia suaveolens mottle virus

Tobacco mosqueado virus

Pepper yellow mosaic virus

Potato virus $\mathrm{Y}-\mathrm{C}$

Potato virus $Y-O$

Potato virus $\mathrm{Y}-\mathrm{N}$

Pepper severe mosaic virus

Bidens mosaic virus

Sunflower chlorotic mottle virus

Sunflower ring blotch virus

Cotyledon virus $Y$

Alstroemeria mosaic virus

Amaranthus leaf mottle virus

Alternanthera mild mosaic virus

Pfaffia mosaic virus

Mashua virus $Y$

Verbena virus $Y$

Bidens mottle virus

Brazilian weed virus $Y$

Amazon lily virus

Tomato necrotic stunt virus

Arracacha mottle virus

Arracacha virus $Y$

Jasmine virus $T$

Plum pox virus

Narcissus degeneration virus

Onion yellow dwarf virus

Ryegrass mosaic virus

Fig. 4. Maximum-likelihood phylogeny of 27 Potato virus $Y$ (PVY)-lineage viruses with five outgroup viruses calculated from the amino acid sequences of the polyproteins encoded by the open reading frames (ORFs) from single representative, mostly complete genomes of each lineage found in GenBank. To create this, the Wild potato mosaic virus ORFs AJ437279 (W) and MK092722 (PN) were used to search the GenBank database, the full genomic sequences of closely related potyviruses were identified and downloaded, and all were aligned. Genomes with black branches were from complete sequences, and those on lighter branches were from partial sequences, mostly their Nlb plus coat protein sequence. Positions and relative branch lengths of the partial sequences were calculated using only those regions shared by the partial and complete polyprotein sequences. Nodes marked with a cross had $>0.90 \mathrm{SH}$ support. Dark circles mark the viruses reported from the Americas and lighter circles mark those from other regions of the world. Viruses grouped under section A are PVY-lineage viruses, those under section B are the most closely related "other potyviruses", those under section C are representative "basal potyviruses", and section D is a rymovirus (Gibbs and Gibbs 2018). 
collection sites. Moreover, only one of them showed evidence of recombination, and WPMV, PVV, and PTV were confirmed to be three distinct but related viruses within the PVY lineage, which is American in origin; therefore, all three apparently evolved in this part of the world.

Further studies are required to provide an improved understanding of WPMV's importance to the pepino crop and the smallholder farmers that grow it. First, a comprehensive survey is required to establish its incidence in Peruvian pepino plantings. Second, WPMV isolates from pepino need to be inoculated to healthy pepino plants to establish their effects on plant growth and fruit yields both alone and in mixed infection with other viruses that infect the crop (currently CMV, PepMV, ToMV, and PVS). In mixedvirus infections potyviruses often stimulate synergistic interactions that greatly increase disease severity (Redinbaugh and Stewart 2018; Untiveros et al. 2007); therefore, study of WPMV's impact in mixed infection would be particularly important here. In addition, inoculation of the WPMV type strain to pepino plants to study its effects on this host would help provide understanding of whether such infection is important for the crop in the presence or absence of other viruses. However, studies on plant growth and fruit yield losses await the development of a healthy stock program to provide virus-tested planting material or the availability of viable botanical seed collected from healthy pepino plants. One WPMV isolate (PN) that came from a diseased pepino plant, which was not passed through single lesions and for which HTS detected no other virus in its culture, was associated with leaf mosaic and deformation symptoms in pepino plants. This is the only information currently available on the effects of single infection with WPMV upon the crop, and there is no information about the effects of mixed-virus infection.

The lethal response to infection exhibited by some combinations of WPMV isolate and solanaceous host species provided a convenient way of establishing the relative virulence of individual isolates and the sensitivities of different host species to infection. Isolate BA seemed highly virulent because it killed the most solanaceous host plant species inoculated by any new pepino isolate. Isolates CA and SC were the least virulent isolates because they killed none (SC) or only one (CA) of the hosts they were inoculated to. N. benthamiana, $P$. floridana, and $S$. chancayense were the most sensitive species because, depending upon the relative virulence of the infecting isolate, they developed the most severe symptoms, often including plant death. $N$. tabacum, $N$. rustica, $N$. occidentalis, and the $N$. bigelovii $\times N$. clevelandii cross were the most tolerant hosts. This is because, in general, they developed the mildest symptoms even with virulent isolates, being killed by such isolates in either no or only one combination of isolate and host species. A lethal systemic necrotic phenotype is typical of strain-specific systemic hypersensitive response to infection involving single-gene resistance (Jones and Vincent 2018; Nyalugwe et al. 2012, 2016a,b). Whether this is so for WPMV needs to be investigated further but, given that $S$. chancayense, $P$. floridana (= pubescens), and Nicandra physaloides are wild plants native to the Andean region, including Peru (Brako and Zarucchi 1993), it constitutes a possible explanation for the plant death caused by some isolates in these hosts. Moreover, wild species of potato and tomato from the Andean region have long been known to provide rich sources of virus resistance genes for use in plant breeding, which suggests that such genes may also be present in other wild solanaceous species (Agrama and Scott 2006; Jones 1981; Roselló et al. 1998; Solomon-Blackburn and Barker 2001; Valkonen 1994). However, this explanation seems unlikely to be correct for the species that developed a lethal necrosis phenotype with most WPMV isolates, Nicotiana benthamiana, because this is native to the Australian continent rather than to the Andean region of South America where WPMV apparently evolved.

WPMV, PVV, PTV, and PVY are biologically and phylogenetically distinct but related viruses, occur in the same region, and infect related hosts. Therefore, it is interesting that these four viruses form clusters in ML phylogenies of their ORFs with closely similar phylogenetic diversity (PD), which can be estimated as the mean pairwise patristic distances of all tips (i.e., sequences) connected through the basal node of each cluster (Fourment and Gibbs 2006). This was done for ML phylogenies of the same alignments used for Figures 3 and 4 after adding or replacing representative sequences of the PVY-O phylogroup (AB711147, HQ912877, and KP691317) and PVY-N phylogroup (KX531041, KY847985, and MH795866) (Gibbs et al. 2017). In both phylogenies, the relative PDs of the four viruses were closely similar; that of the WPMV cluster was only 5 to $6 \%$ smaller than that of the PVV cluster, only 2 to $3 \%$ smaller than that of the PTV cluster, and $10 \%$ larger than that of the PVY cluster.

WPMV, PVV, PTV, and six other viruses originally isolated from solanaceous plants all belonged to the smaller of the two sublineages within the overall PVY lineage. All except 2 of the 27 viruses of the PVY lineage were isolated in the Americas, and 17 of them have never been found anywhere else. Moreover, the two not reported first from the Americas still have links with this part of the world. The first, Amazon lily mosaic virus, was isolated from Eucharis grandiflora, a native of Colombia and Ecuador, and was being grown for its flowers in Taiwan (Fuji et al. 2004). The second, Amaranthus leaf mottle virus, was isolated from Argentina amaranth (Amaranthus diflexus) growing in Italy (Lovisolo and Lisa 1976; Segundo et al. 2007). This strong association of the PVY lineage with the Americas suggests that it diversified there. However, similar inferences about the basal monocotyledon-infecting viruses of the genus Potyvirus suggest that it originated in Western Europe or northwest Africa (Gibbs and Ohshima 2010). If so, an interesting question is how and when did the original ancestor of the PVY lineage migrate from the Old World to the New? More intensive sampling of the populations of the most basal potyviruses in lineages A to D (Fig. 4) (e.g., Arracacha virus $Y$; synonym Arracacha mottle virus) (Adams et al. 2018a) in A would be required to resolve this question.

Currently, all we know about WPMV's epidemiology in pepino crops is that its spread is likely to occur through nonpersistent transmission by aphid vectors such as Myzus persicae (Jones and Fribourg 1979) and planting infected pepino cuttings. However, movement of infected pepino cuttings between Peru's coastal valleys would explain the lack of any relationship between the phylogenetic distance between WPMV isolates and geographical distance between their collection sites. Although potato and pepper were not infected, tomato and tobacco were experimental hosts of the WPMV type strain (Jones and Fribourg 1979) and tobacco became infected with isolates from pepino in this study. When inoculated in the greenhouse, the wild tomato species $S$. pimpinellifolium became infected with two WPMV isolates from pepino, and the latter species, along with two other wild tomato species ( $S$. chilense and $S$. peruvianum), became infected with another pepino virus (PepMV) in the Peruvian coastal desert region (López et al. 2005; Moreno-Pérez et al. 2014). The possible role of tomato, tobacco, wild tomato and wild potato species, and solanaceous agricultural weed hosts such as $P$. floridana (= pubescens) and Nicandra physaloides in acting as reservoirs of infection for WPMV spread to pepino crops needs to be investigated in the future. The same applies to local climatic drivers of WPMV epidemics in pepino crops. Spread of the virus within the Lomas vegetation also requires attention, including establishing which wild solanaceous species other than $S$. chancayense become infected there, if it poses any threat to the natural ecosystem, and whether the virus spreads readily from this natural vegetation to pepino crops. Regarding WPMV disease management in crops, making healthy pepino planting stock available for use by smallholder farmers seems a logical place to start.

PepMV provides a classic example of a virus formerly localized to one continent being dispersed to the rest of the world via the international seed crop trade, resulting in a serious disease of tomato crops in many continents (Hanssen and Thomma 2010; Jones 2009). Now that we know that WPMV constitutes a potential threat to some solanaceous crops, its seed transmission needs to be investigated as a potential pathway for WPMV dispersion outside South America. Distribution of virus-infected pepino cuttings from South America to another part of the world has already been reported (Dolby and Jones 1988; Thomas et al. 1980). Therefore, importing pepino 
cuttings should be avoided unless rigorous postentry quarantine testing for viruses and procedures for their elimination are in place in the importing country.

\section{Acknowledgments}

The biological component of this research was undertaken using the glasshouse and laboratory facilities of the International Potato Center (CIP) in 1976 to 1978 and the National Agrarian University in 2014 to 2016, both at La Molina, Lima, Peru. The sequencing component of this research was done using the laboratory facilities of Fera Ltd., Sand Hutton, York, U.K. R. A. C. Jones was an employee of CIP in 1973 to 1978

\section{Literature Cited}

Abascal, F., Zardoya, R., and Telford, M. J. 2010. TranslatorX: Multiple alignment of nucleotide sequences guided by amino acid translations. Nucleic Acids Res. 38:W7-W13.

Adams, I. P., Boonham, N., and Jones, R. A. C. 2018a. Full-genome sequencing of a virus from a 33-year-old sample demonstrates that Arracacha mottle virus is synonymous with Arracacha virus Y. Microbiol. Resour. Announce. 7:e0139318.

Adams, I. P., Fox, A., Boonham, N., and Jones, R. A. C. 2018b. Complete genomic sequence of the potyvirus Mashua virus $Y$, obtained from a 33-year-old mashua (Tropaeolum tuberosum) sample. Microbiol. Resour. Announce. 7: e01064-18.

Agrama, H. A., and Scott, J. W. 2006. Quantitative trait loci for tomato yellow leaf curl virus and tomato mottle virus resistance in tomato. J. Am. Soc. Hortic. Sci. 131:267-272.

Altschul, S. F., Gish, W., Miller, W., Myers, E. W., and Lipman, D. J. 1990. Basic local alignment search tool. J. Mol. Biol. 215:403-410.

Ball, E. M. 1974. Serological Tests for the Identification of Plant Viruses. American Phytopathological Society, St. Paul, MN, U.S.A.

Bercks, R., Koenig, R., and Querfurth, G. 1972. Plant virus serology. Pages 466-490 in: Principles and Techniques in Plant Virology. C. I. Kado and H. O. Agrawal, eds. Van-Nostrand-Reinhold, New York, NY, U.S.A.

Blanca, J. M., Prohens, J., Anderson, G. J., Zuriaga, E., Cañizares, J., and Nuez, F. 2007. AFLP and DNA sequence variation in an Andean domesticate, pepino (Solanum muricatum, Solanaceae): Implications for evolution and domestication. Am. J. Bot. 94:1219-1229.

Boni, M. F., Posada, D., and Feldman, M. W. 2007. An exact nonparametric method for inferring mosaic structure in sequence triplets. Genetics 176: 1035-1047.

Brako, L., and Zarucchi, J. L. eds. 1993. Catalogue of the Flowering Plants and Gymnosperms of Peru. Monogr. Syst. Bot. Missouri Bot. Gard. 45.

Camacho, C., Coulouris, G., Avagyan, V., Ma, N., Papadopoulos, J., Bealer, K., and Madden, T. L. 2009. BLAST+: Architecture and applications. BMC Bioinf. 10:421.

Clark, M. F., and Adams, A. N. 1977. Characteristics of the microplate method of enzyme-linked immunosorbent assay for the detection of plant viruses. J. Gen. Virol. 34:475-483.

Damsteegt, V. D., Stone, A. L., Smith, O. P., McDaniel, L., Sherman, D. J., Dardick, C., Hammond, J., Jordan, R., and Schneider, W. L. 2013. A previously undescribed potyvirus isolated and characterized from arborescent Brugmansia. Arch. Virol. 158:1235-1244.

Dillon, M. O. 2005. The Solanaceae of the Lomas formations of coastal Peru and Chile. Monogr. Syst. Bot. 104:131-156.

Dolby, C. A., and Jones, R. A. C. 1988. The relationship between the Andean strain of potato virus S and pepino latent virus. Ann. Appl. Biol. 112: 231-234.

Fernandez-Northcote, E. N., and Fulton, R. W. 1980. Detection and characterization of Peru tomato virus strains infecting pepper and tomato in Peru. Phytopathology 70:315-320.

Fernandez-Northcote, E. N., Navarro, D., and Fribourg, C. E. 1982. Deteccion en el Peru del virus del mosaico del pepinillo (CMV) en pepino (Solanum muricatum). (Abstr.) Fitopatologia 17:10.

Fourment, M., and Gibbs, M. J. 2006. PATRISTIC: A program for calculating patristic distances and graphically comparing the components of genetic change. BMC Evol. Biol. 6:1.

Francki, R. I. B., Mossop, D. W., and Hatta, T. 1979. Cucumber mosaic virus. CMI/AAB Descriptions of Plant Viruses No. 213. Association of Applied Biologists, Wellesbourne, U.K

Fribourg, C. E. 1979. Host plant reactions, some properties, and serology of Peru tomato virus. Phytopathology 69:441-445.

Fribourg, C. E., and Fernandez-Northcote, E. N. 1982. Peru tomato virus. CMI/ AAB Descriptions of Plant Viruses, No. 255. Association of Applied Biologists, Wellesbourne, U.K

Fribourg, C. E., Jones, R. A. C., and Koenig, R. 1977a. Host plant reactions, physical properties and serology of three isolates of Andean potato latent virus from Peru. Ann. Appl. Biol. 86:373-380.

Fribourg, C. E., Jones, R. A. C., and Koenig, R. 1977b. Andean potato mottle, a new member of the cowpea mosaic virus group. Phytopathology 67: 969-974.
Fribourg, C. E., and Nakashima, J. 1984. Characterization of a new potyvirus from potato. Phytopathology 74:1363-1369.

Fuji, S., Terami, F., Furuya, H., Naito, H., and Fukumoto, F. 2004. Nucleotide sequence of the coat protein genes of alstroemeria mosaic virus and amazon lily mosaic virus, a tentative species of genus potyvirus. Arch. Virol. 149: 1843-1849.

Gibbs, A. J., and Gibbs, M. J. 2018. Rymovirus: A cautionary tale. Arch. Virol. 163:815-817

Gibbs, A. J., and Ohshima, K. 2010. Potyviruses and the digital age. Annu. Rev. Phytopathol. 48:205-223.

Gibbs, A. J., Ohshima, K., Yasaka, R., Mohammad, M., Gibbs, M. J., and Jones, R A. C. 2017. The phylogenetics of the global population of Potato virus $Y$ and its necrogenic recombinants. Virus Evol. 3:vex002.

Gibbs, M. J., Armstrong, J. S., and Gibbs, A. J. 2000. Sister-scanning: A Monte Carlo procedure for assessing signals in recombinant sequences. Bioinformatics 16:573-582

Grabherr, M. G., Haas, B. J., Yassour, M., Levin, J. Z., Thompson, D. A., Amit, I. Adiconis, X., Fan, L., Raychowdhury, R., Zeng, Q., Chen, Z., Mauceli, E., Hacohen, N., Gnirke, A., Rhind, N., di Palma, F., Birren, B. W., Nusbaum, C., Lindblad-Toh, K., Friedman, N., and Regev, A. 2011. Full-length transcriptome assembly from RNA-Seq data without a reference genome. Nat. Biotechnol. 29:644-652.

Guindon, S., and Gascuel, O. 2003. A simple, fast, and accurate algorithm to estimate large phylogenies by maximum likelihood. Syst. Biol. 52:696-704.

Hall, T. A. 1999. BioEdit: A user-friendly biological sequence alignment editor and analysis program for Windows 95/98/NT. Nucleic Acids Symp. Ser. 41:95-98.

Hanssen, I. M., and Thomma, B. P. 2010. Pepino mosaic virus: A successful pathogen that rapidly evolved from emerging to endemic in tomato crops. Mol. Plant Pathol. 11:179-189.

Herraiz, F. J., Raigón, M. D., Vilanova, S., García-Martínez, M. D., Gramazio, P., Plazas, M., Rodríguez-Burruezo, A., and Prohens, J. 2016. Fruit composition diversity in land races and modern pepino (Solanum muricatum) varieties and wild related species. Food Chem. 203:49-58

Herraiz, F. J., Vilanova, S., Andújar, I., Torrent, D., Plazas, M., Gramazio, P., and Prohens, J. 2015. Morphological and molecular characterization of local varieties, modern cultivars and wild relatives of an emerging vegetable crop, the pepino (Solanum muricatum), provides insight into its diversity, relationships and breeding history. Euphytica 206:301-318.

Hinostroza-Orihuela, A. M. 1973. Some properties of potato virus S isolated from Peruvian potatoes. Potato Res. 16:244-250.

Hollings, M., and Huttinga, H. 1976. Tomato mosaic virus. CMI/AAB Descriptions of Plant Viruses No. 156. Association of Applied Biologists, Wellesbourne, U.K

Holmes, E. C., Worobey, M., and Rambaut, A. 1999. Phylogenetic evidence for recombination in dengue virus. Mol. Biol. Evol. 16:405-409.

Huson, D. H., Beier, S., Flade, I., and Gorska, A. 2016. MEGAN community edition-Interactive exploration and analysis of large-scale microbiome sequencing data. PLOS Comput. Biol. 12:e1004957.

Jones, R. A. C. 1981. The ecology of viruses infecting wild and cultivated potatoes in the Andean Region of South America. Pages 89-107 in: Pests, Pathogens and Vegetation. J. M. Thresh, ed. Pitman, London, U.K.

Jones, R. A. C. 2009. Plant virus emergence and evolution: Origins, new encounter scenarios, factors driving emergence, effects of changing world conditions, and prospects for control. Virus Res. 141:113-130.

Jones, R. A. C., and Fribourg, C. E. 1979. Host plant reactions, some properties, and serology of wild potato mosaic virus. Phytopathology 69:446-449.

Jones, R. A. C., and Fribourg, C. E. 1986. AAB Descriptions of Plant Viruses No. 316, Vol. CMI: Potato virus. Association of Applied Biologists, Wellesbourne, U.K.

Jones, R. A. C., and Fribourg, C. E. 1990. Wild potato mosaic virus. Pages 608-610 in: Viruses of Tropical Plants. Descriptions and Lists from the VIDE Database. A A. Brunt, K. Crabtree, and A. J. Gibbs, eds. CAB International, Wallingford, U.K. https://www.cabdirect.org/cabdirect/abstract/19912304303

Jones, R. A. C., Koenig, R., and Lesemann, D. E. 1980. Pepino mosaic virus, a new potexvirus from pepino (Solanum muricatum). Ann. Appl. Biol. 94:61-68.

Jones, R. A. C., and Vincent, S. J. 2018. Strain-specific hypersensitive and extreme resistance phenotypes elicited by Potato virus $Y$ among 39 potato cultivars released in three world regions over a 117 Year Period. Plant Dis. 102:185-196.

Joshi, N. A., and Fass, J. N. 2011. Sickle-A windowed adaptive trimming tool for FASTQ files using quality. https://github.com/najoshi/sickle

Katoh, K., and Standley, D. M. 2013. MAFFT multiple sequence alignment software version 7: Improvements in performance and usability. Mol. Biol Evol. 30:772-780.

Kim, Y. J., Jonson, M. G., Choi, H. S., Ko, S. J., and Kim, K. H. 2009. Molecular characterization of Korean Pepper mottle virus isolates and its relationship to symptom variations. Virus Res. 144:83-88.

Kumar, S., Stecher, G., and Tamura, K. 2016. MEGA7: Molecular evolutionary genetics analysis version 7.0 for bigger datasets. Mol. Biol. Evol. 33:1870-1874

Lemey, P., Lott, M., Martin, D. P., and Moulton, V. 2009. Identifying recombinants in human and primate immunodeficiency virus sequence alignments using quartet scanning. BMC Bioinf. 10:126.

López, C., Soler, S., and Nuez, F. 2005. Comparison of the complete sequences of three different isolates of Pepino mosaic virus: Size variability of the TGBp3 protein between tomato and L. peruvianum isolates. Arch. Virol. 150:619-627. 
Lovisolo, O., and Lisa, V. 1976. Characterization of a virus isolated from Amaranthus deflexus, serologically related to bean yellow mosaic virus. Agric. Conspectus Sci. 39:553-559.

Martin, D., and Rybicki, E. 2000. RDP: Detection of recombination amongst aligned sequences. Bioinformatics 16:562-563.

Martin, D. P., Murrell, B., Golden, M., Khoosal, A., and Muhire, B. 2015. RDP4: Detection and analysis of recombination patterns in virus genomes. Virus Evol. 1:vev003.

Martin, D. P., Posada, D., Crandall, K. A., and Williamson, C. 2005. A modified BOOTSCAN algorithm for automated identification of recombinant sequences and recombination breakpoints. AIDS Res. Hum. Retroviruses 21:98-102.

Maynard-Smith, J. 1992. Analyzing the mosaic structure of genes. J. Mol. Evol. 34:126-129.

McGuire, G., and Wright, F. 2000. TOPAL 2.0: Improved detection of mosaic sequences within multiple alignments. Bioinformatics 16:130-134.

Moreira, A., Jones, R. A. C., and Fribourg, C. E. 1980. Properties of a resistancebreaking strain of potato virus X. Ann. Appl. Biol. 95:93-103.

Moreno-Pérez, M. G., Pagán, I., Aragón-Caballero, L., Cáceres, F., Fraile, A., and García-Arenal, F. 2014. Ecological and genetic determinants of Pepino mosaic virus emergence. J. Virol. 88:3359-3368.

Muhire, B. M., Varsani, A., and Martin, D. P. 2014. SDT: A virus classification tool based on pairwise sequence alignment and identity calculation. PLoS One 9: e108277.

Nyalugwe, E. P., Barbetti, M. J., Clode, P. L., and Jones, R. A. C. 2016a. Systemic hypersensitive resistance to Turnip mosaic virus in Brassica juncea is associated with multiple defence responses, especially phloem necrosis and xylem occlusion. Plant Dis. 100:1261-1270.

Nyalugwe, E. P., Barbetti, M. J., and Jones, R. A. C. 2016b. Strain specificity of Turnip mosaic virus resistance gene TuRBJ01 in Brassica juncea. Eur. J. Plant Pathol. 145:209-213.

Nyalugwe, E. P., Wilson, C. R., Coutts, B. A., and Jones, R. A. C. 2012. Biological properties of Potato virus $X$ in potato: Effects of mixed infection with Potato virus $S$ and resistance phenotypes in cultivars from three continents. Plant Dis. 96:43-54.

Padidam, M., Sawyer, S., and Fauquet, C. M. 1999. Possible emergence of new geminiviruses by frequent recombination. Virology 265:218-225.

Posada, D., and Crandall, K. A. 2001. Evaluation of methods for detecting recombination from DNA sequences: Computer simulations. Proc. Natl. Acad. Sci. U.S.A. 98:13757-13762.

Prohens, J., Ruiz, J. J., and Nuez, F. 1996. The pepino (Solanum muricatum, Solanaceae): A "new" crop with a history. Econ. Bot. 50:355-368.

Redinbaugh, M. G., and Stewart, L. R. 2018. Maize lethal necrosis: An emerging, synergistic viral disease. Annu. Rev. Virol. 5:301-322.

Roberts, I. M. 1982. Practical aspects of handling, preparing and staining samples containing plant viruses for electron microscopy. Pages 213-243 in: Developments in Applied Biology 1: Developments and Applications for
Virus Testing. R. A. C. Jones and L. Torrance, eds. Association of Applied Biologists, Wellesbourne, Warwick, U.K.

Roossinck, M. J. 2010. Lifestyles of plant viruses. Philos. Trans. R. Soc. Lond. B Biol. Sci. 365:1899-1905.

Roselló, S., Díez, M. J., and Nuez, F. 1998. Genetics of tomato spotted wilt virus resistance coming from Lycopersicon peruvianum. Eur. J. Plant Pathol. 104: 499-509.

Santillan, F., Fribourg, C., Adams, I., Gibbs, A. J., Boonham, N., Kehoe, M. Maina, S., and Jones, R. A. C. 2018. The biology and phylogenetics of Potato virus $S$ isolates from the Andean region of South America. Plant Dis. 102:869-885.

Santillan, F. W. 1979. Estudio comparativo de 11 aislamientos de virus S de la region Andina. M.Sc. thesis, National Agrarian University, La Molina, Lima, Peru.

Santillan, F. W., Fribourg, C. E., and Jones, R. A. C. 1980. Estudio comparativo de once aislamientos de virus $\mathrm{S}$ de la papa de la region Andina. (Abstr.) Fitopatologia 15:42-43.

Segundo, E., Lesemann, D. E., Martin, G., Carmona, M. P., Ruiz, L., Cuadrado, I. M., Velasco, L., and Janssen, D. 2007. Amaranthus leaf mottle virus: 3 '-End RNA sequence proves classification as distinct virus and reveals affinities within the genus Potyvirus. Eur. J. Plant Pathol. 117:81-87.

Shamsadden-Saeed, F., Massumi, H., Moradi, S., Maddahian, M., Heydarnejad, J., Pour, A. H., and Varsani, A. 2014. Incidence and characterization of Potato virus $V$ infections in Iran. Virus Dis. 25:78-84.

Shimodaira, H., and Hasegawa, M. 1999. Multiple comparisons of loglikelihoods with applications to phylogenetic inference. Mol. Biol. Evol. 16:1114-1116.

Solomon-Blackburn, R. M., and Barker, H. 2001. A review of host major-gene resistance to potato viruses $\mathrm{X}, \mathrm{Y}, \mathrm{A}$ and $\mathrm{V}$ in potato: Genes, genetics and mapped locations. Heredity 86:8-16

Spetz, C., Taboada, A. M., Darwich, S., Ramsell, J., Salazar, L. F., and Valkonen, J. P. T. 2003. Molecular resolution of a complex of potyviruses infecting solanaceous crops at the centre of origin in Peru. J. Gen. Virol. 84 2565-2578.

Spetz, C., and Valkonen, J. P. T. 2003. Genomic sequence of Wild potato mosaic virus as compared to the genomes of other potyviruses. Arch. Virol. 148: 373-380.

Thomas, W., Mohamed, N. A., and Fry, M. E. 1980. Properties of a carlavirus causing a latent infection in pepino (Solanum muricatum). Ann. Appl. Biol. 95:191-196.

Untiveros, M., Fuentes, S., and Salazar, L. F. 2007. Synergistic interaction of Sweet potato chlorotic stunt virus (Crinivirus) with carla-, cucumo-, ipomo-, and potyviruses infecting sweet potato. Plant Dis. 91:669-676.

Valkonen, J. P. T. 1994. Resistance to viruses in cultivated and wild potato species (Solanum spp.). Plant Breed. 112:1-16. 